\title{
Forest regeneration appraisal with large-scale aerial photographs
}

\author{
by R.J. Hall ${ }^{1}$ and A.H. Aldred ${ }^{2}$
}

\begin{abstract}
The operational feasibility of using large-scale aerial photographs to quantify coniferous forest stocking and regeneration density, was assessed over 6 cutovers with a 1,700 ha total area. The project involved two stages: one to pre-stratify cutover stocking levels using 1:10,000 general-coverage, colour photos; and the second to sample intensively, stocking and density using 1:500 large-scale photos. The accuracy, cost and practical problems in using large-scale sampling photos for regeneration assessment were determined. Accuracy assessment included detectability of young trees, species interpretation, and reliability of stocking and density measurements. Stocking estimates were on average, only five percent lower than field survey results but could be calibrated using regression techniques. Large differences between field survey and photo estimates of density in stems/ha suggested such counts should not be made from largescale photos. Density count differences were attributable to seedlings occurring in dense patches or clumps where field counts were also difficult. If survey objectives and methods are carefully planned, large-scale photos can be a suitable tool for assessing and monitoring the stocking and survival rates of coniferous forest regeneration.
\end{abstract}

Key words: Forest regeneration appraisal, silviculture, inventory, sampling, large-scale photography.

\section{Introduction}

The drive towards more intensive forest management was reported in a recent study on Canada's silvicultural performance (Kuhnke 1989). Initiatives have stressed the importance of returning unstocked or partially stocked forest land to full production through forest regeneration. These trends have raised interest in evaluating the capability of large-scale aerial photographs (LSP) for assessing conifer stocking and density (Hall 1984). Although the application of LSP to regeneration assessments has been reported by several agencies (Ball and Kolabinski 1979; Kirby 1980; Goba et al. 1982; Butler 1983; Hall 1984; Ashely and Cohen 1985; Hudson 1985; Smith et al. 1986), operational use has been slow to gather momentum. Price Waterhouse (1984) partially attributed this to the general unawareness of LSP capabilities for regeneration surveys, variable forestry conditions across Canada, and perceived limited availability of LSP services. There are however, several companies that do offer the necessary services (Hall et al. 1984). LSP technology has also been used for forest inventory in the Northern Territories, Yukon, British Columbia, Alberta, Ontario and the Maritimes by

'Forestry Canada, Northwest Region, Northern Forestry Centre, 5320-122 Street, Edmonton, Alberta, Canada T6H 3S5.

${ }^{2}$ Dendron Resource Surveys Ltd., Ottawa, Ontario.

\section{Résumé}

La faisabilité opérationnelle de l'utilisation de photographies aériennes à grande échelle pour quantifier le stocking des forêts de coniferes et la densité de la régénération, a été évaluée pour 6 coupes à blanc d'une superficie totale de 1700 ha. Le projet comprenait deux étapes : une première qui pré-stratifiait les niveaux de stocking des coupes à blanc au moyen de photographies de couverture générale en couleur à l'échelle de 1:10 000; et la deuxième qui échantillonnait de façon intensive, le stocking et la densité en utilisant des photographies à grande échelle de 1:5 000. La précision, les coûts et les problèmes pratiques d'utilisation des photos à grande échelle à des fins d'échantillonnage pour l'évaluation de la régénération ont été établis. L'évaluation de la précision comprenait la détection des jeunes arbres, l'interprétation des essences, et la fiabilité des mesures de stocking et de densité. Les estimés de stocking étaient en moyenne, seulement cinq pourcent inférieurs aux résultats provenant du terrain, mais pouvaient être calibrés en utilisant des techniques de régression. Les grandes différences entre le sondage sur le terrain et les estimés des photos au niveau de la densité en terme d'arbres par hectare suggéraient qu'un tel dénombrement ne devrait pas être fait à partir de photos à grande échelle. Les différences dans le dénombrement de la densité étaient attribuables aux semis croissants en groupe dense ou très rapprochés, conditions qui rendaient également difficiles le dénombrement sur le terrain. A la condition que les objectifs et les méthodes soient soigneusement planifés, les photos à grande échelle peuvent être un outil adéquat pour évaluer et superviser les taux de stocking et de survie de la régénération des forêts de conifères.

Mots clés : Evaluation de la régénération forestière, sylviculture, inventaire, échantillonnage, photos à grande échelle.

government and industry on a periodic inventory, special survey, or trial basis (Neilsen et al. 1979; Befort 1988; Spencer and Hall 1988). This project focused on regeneration assessment applications of LSP under Saskatchewan Boreal conditions with particular attention given to the information needs of practising foresters.

The study was initiated by Weyerhaeuser Canada Ltd., and the Forestry Division of Saskatchewan Parks and Renewable Resources (SPRR), in cooperation with Forestry Canada. Dendron Resource Surveys Ltd., under the Canada/ Saskatchewan Forest Resource Development Agreement, carried out the LSP survey.

This study was performed over approximately 1,700 ha, comprising both recent cutovers and backlog areas and concentrated on coniferous species. The specific objectives were:

1. To produce a map of each cutover to delineate the unproductive areas and stratify the productive areas based on their stocking status;

2. To assess conifer stocking by species within a $10 \%$ allowable error at the $95 \%$ confidence interval by strata within each cutover; and

3. To assess the capability of LSP to reduce the costly process of assessing regeneration plots by direct relation 
to field measurements using double sampling for stocking, density, species identification, and percent detection by height class and by species.

The purpose of this article is to describe the LSP methodology and the results of tests on six cutover areas.

\section{Study Area}

The study area consisted of six cutovers located about $110 \mathrm{~km}$ northwest of Prince Albert, Saskatchewan, adjacent to Prince Albert National Park (Figure 1). The study area is within the Mixed Boreal Forest Region (B.18a, Rowe, 1972) characterized by mixtures of trembling aspen (Populus tremuloides Michx.), balsam poplar (Populus balsamifera L.), white birch (Betula papyrifera Marsh.), white spruce (Picea glauca [Moench] Voss) and balsam fir (Abies balsamea [Mill.] B.S.P.) were found respectively, on sites of drier and wetter extremes.

The six sites totalled 1,716 ha (Table 1). The Weyerhaeuser sites (PA's) were harvested for pulpwood 5 to 7 years previously, and scarified before planting or natural regeneration. The provincial sites (DP's) ranged from 8 to 23 years since harvesting.

\section{Survey Methodology}

The regeneration survey methodology to assess the six cutover sites consisted of two primary phases. The first phase entailed air photo acquisition followed by interpretation and mapping for areal stratification. The second phase utilized large-scale photos (LSP) to sample the degree of stocking and density of regeneration.

The primary role of LSP was to reduce, but not eliminate, the costly process of establishing and assessing regeneration

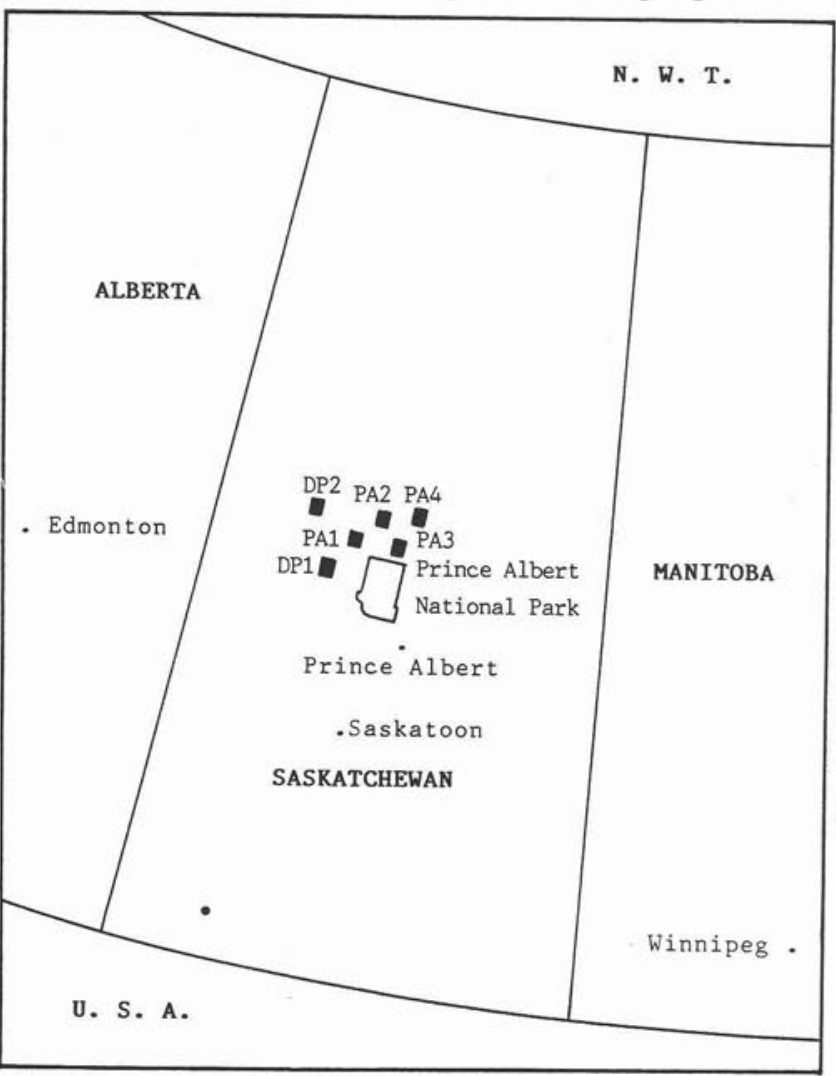

Figure 1. Location of the six test sites used in the study.
Table 1. The areal size of each site sampled

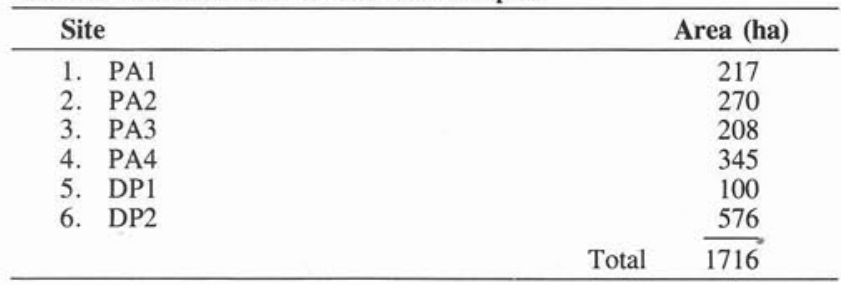

plots in the field. Clusters of quadrats were marked on the photos, and the stocking and density of trees by species and size class (height) were assessed analogous to field sampling.

\section{Pre-stratification}

The purpose of the pre-stratification was to separate the productive from the non-productive forest land. The productive areas were further stratified into more homogenous subunits characterizing different attributes or stocking levels (Table 2). The minimum delineated area was 20 ha based on a given specification of a minimum treatable unit. The delineated classes and codes were transferred to a base map of each site with a Mapograph. Base maps consisted of SPRR (provincial) forest cover maps at a scale of $1: 12,500$. The basis for the LSP sampling design was the provisional stratified cutover maps prepared for each site (Figure 2).

\section{Sampling Design}

The sampling design followed the general multi-stage sampling procedures described by Hazard and Steward (1974). The design was a two-stage random sampling with a double sampling strategy. The design was described by Hall (1984) and statistical derivations developed in detail by Bonner (1975) and MacLeod (1981, 1982).

\section{Large-scale Photo Acquisition}

The large-scale sampling photos were obtained in early spring on May 6 and 7, 1987, according to the sampling design. The airborne system is illustrated (Figure 3). A total of eight, 100-foot rolls of LSP were exposed (about 4000 stereo pairs) during the project and one tracking film. An initial sample of about 900 sample photo plots were drawn at random, covering the six strata and prepared for plot establishment, interpretation and measurement.

\section{LSP Interpretation and Measurement}

The sample plot cluster was positioned on the photos (Figure 4). The $4 \times 4$ cluster of sixteen $-5 \mathrm{~m}^{2}$ quadrats were designed to be $80 \mathrm{~m}^{2}$ in size, but varied somewhat because

Table 2. Photo interpretation stratification legend

\begin{tabular}{lll}
\hline Non-productive forest land & Productive forest land & \\
\hline Water & Unlogged & UL \\
Bogs & Logged & \\
Swamps & Cutover & \\
Rock outcrops & 1. Stocked & CC1 \\
Brush & 2. Partially stocked & CC2 \\
Roads & 3. NSR (unstocked) & CC3 \\
Openings & Partial cut & \\
Landings & 1. Stocked & PC1 \\
& 2. Partially stocked & PC2 \\
& 3. NSR & PC3
\end{tabular}

The logged areas were further characterized as planted (PL) or naturally regenerated (NAT). 


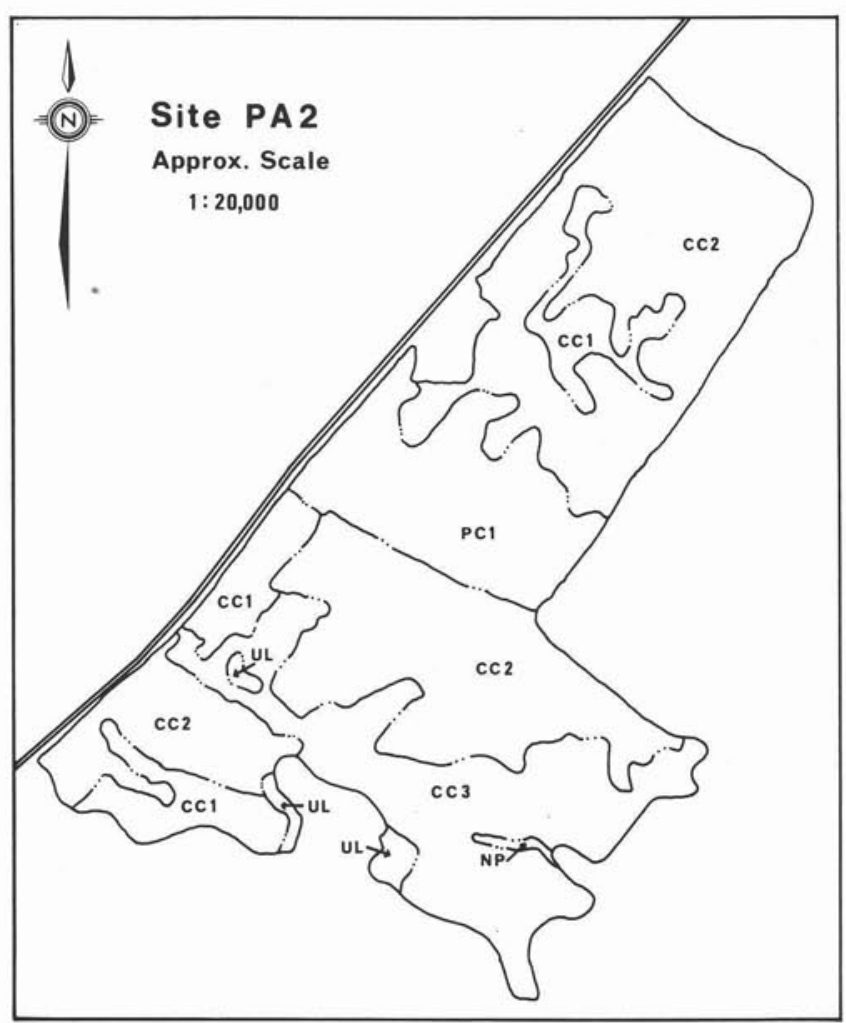

Figure 2. Photo interpreted stratification map.

of variations in photo scale. The quadrat size reflected the regeneration survey stocking standard established by the province of Saskatchewan (Saskatchewan Parks and Renewable Resources 1985). An overlay template was prepared for the four corners, to tie-in to the photo fiducial marks and to handle scale changes. Two other cluster configurations were also tested: $3 \times 3$ (nine $5-\mathrm{m}^{2}$ quadrats) with a plot area of $45 \mathrm{~m}^{2}$, and $2 \times 2$ (four $5-\mathrm{m}^{2}$ quadrats) with a plot area of $20 \mathrm{~m}^{2}$.

Each stereo pair of photos was mounted on the Zeiss Stereocord photogrammetric plotter (Figure 5). Microcomputer software controlled the entry of reference data (plot number, site number, stratum, 1:10,000 photo number cross reference), the photogrammetric data (flying height, pitch and roll) and the measurement of the plot (location of corners, subplot partitioning and determination of plot area). A plot map is illustrated (Figure 4).

\section{Field Work}

The purpose of the field work was to provide double samples, and to evaluate the effectiveness of LSP as a regeneration survey method. Sixty large-scale photo plotclusters were selected for ground survey with half on partialcut areas, and half on cutover areas. All six strata were represented. The large-scale photo plot clusters were located in the field with the use of the 1:2,000 scale tracking photos.

\section{Stocking and Density Compilation}

The plot and seedling data were sorted by site and stratum. The average percent stocking and average density (trees per hectare) by species, and for all species, were calculated with an estimate of accuracy. These estimators were determined by the sampling design and desired level of accuracy

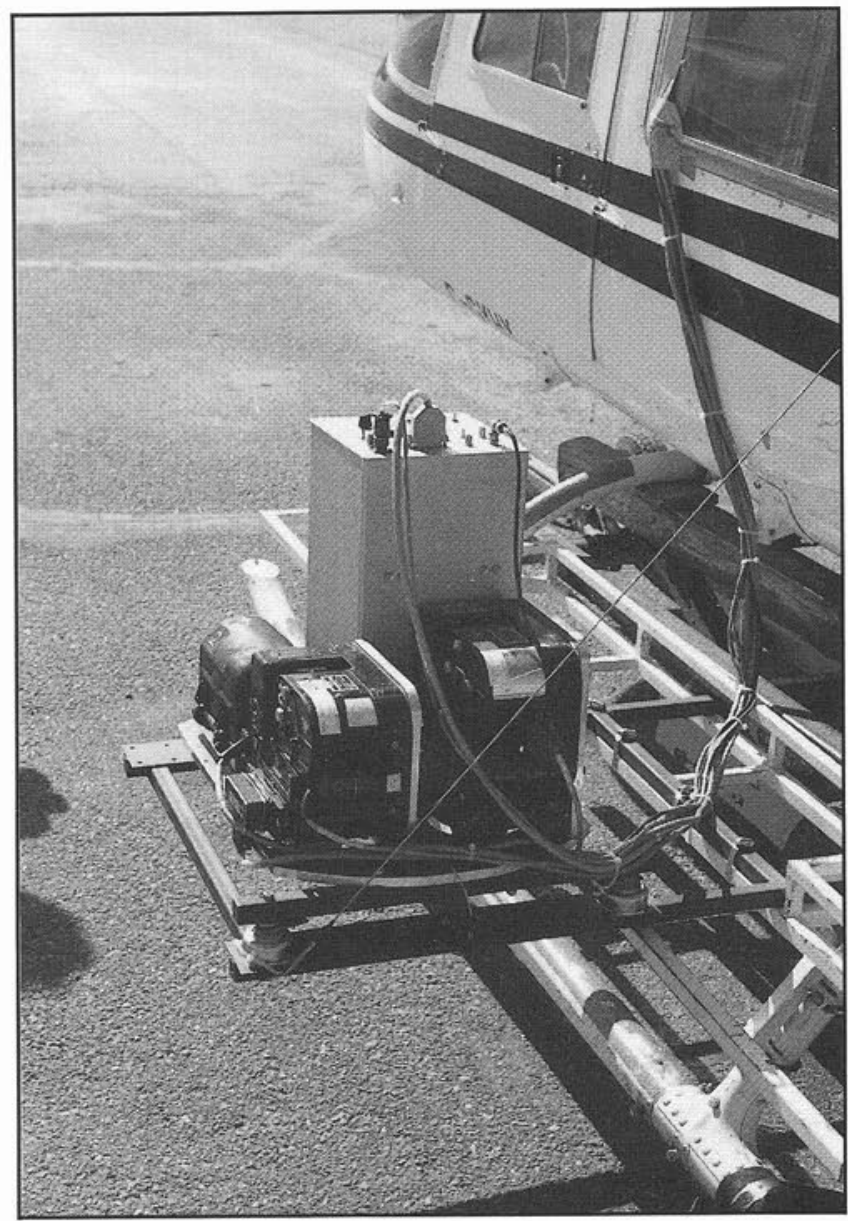

Figure 3. Dendron Resource Surveys Ltd. airborne system mounted on a Bell 206B helicopter.

( \pm 10 percent) and confidence ( 95 percent). The data list beside the plot map (Figure 4) shows the origin of data used to compile the estimates. Following analysis of the 60 paired plots, estimates were corrected for small photo measurement biases.

\section{Results from the Analysis of Paired Plots}

The paired plot assessment included percent conifer seedling detection, species identification accuracy, stocking and density estimation, and the development of correction equations to adjust for systematic differences between photo and field results. The distribution of the sixty paired plots covering the three sites and the six strata were summarized (Table 3).

\section{Detectability}

An important question about the capability of LSP for regeneration surveys was:

What proportion of conifer seedlings would likely go undetected?

A tree may be missed because it is either too small to be seen, or it is hidden among or beneath other trees. A borderline tree may be rejected when it is actually within the plot. The first reason is important because it expresses a limitation of the method. The second is less important within the stocking context since a group of trees may succumb to competition, 

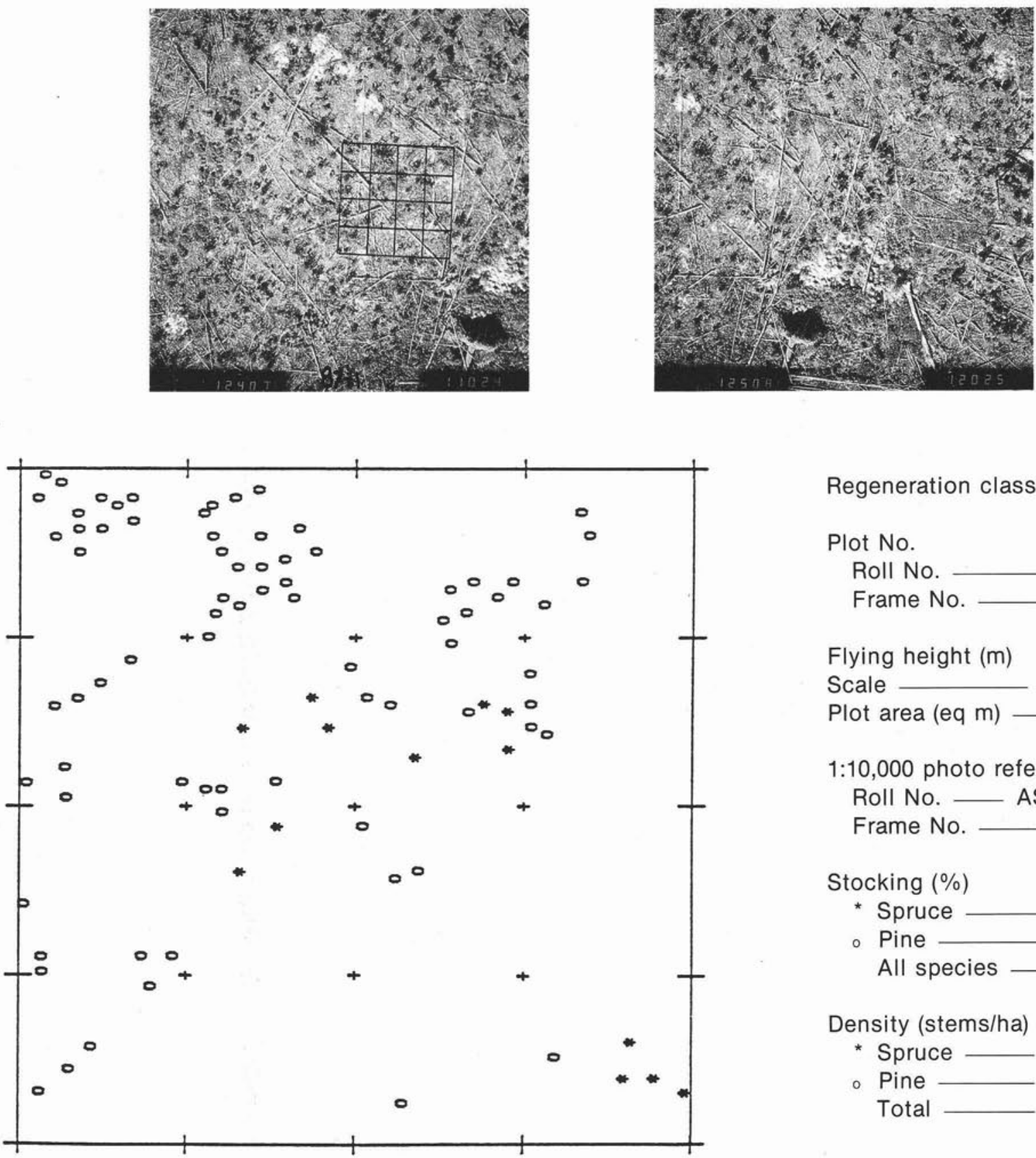
Regeneration class - CC2
Plot No.
Roll No. -1
Frame No. 124
Flying height $(\mathrm{m}) \quad-\quad 80$
Scale 1: 533
Plot area (eq m)
1:10,000 photo reference
Roll No. _ AS86103
Frame No. _ 66
$\begin{array}{ll}\begin{array}{l}\text { Stocking (\%) } \\ \text { * Spruce }\end{array} & 25 \\ & 88 \\ \text { - Pine } & 88 \\ \text { All species } & 88\end{array}$
Density (stems/ha)
* Spruce — 1680
- Pine — 9819
Total 11499

Figure 4. Large-scale photos with $4 \times 4$ quadrat sampling grid, above; and beneath, a stand map of gridded area plotted and summarized by measurement system.

but not affect the stocking of the eventual mature stand. The third reason is least important because omitted trees along the plot boundary are likely to be balanced by commissions (trees called inside when they are actually outside).

Density was considered less important than the spacing of trees in assessing stocking. It is of limited value in expressing how well growing space would be utilized by a developing stand (Dendron Resource Surveys 1983). Detectability was expressed as the difference in photo versus field plot count. Overall, 66 percent of the trees on the field plots were detected on the photo plots (Table 4). Most of the difficulty arose from separating seedlings individually when they occurred in dense patches.

\section{(a) Seedling detectability over cutover areas}

Cutover sites were usually dominated by naturally regenerated jack pine, which were often growing in closely associated clumps of up to 10 or more seedlings. The problem in determining the exact number of seedlings in a given plot was due to the clumping characteristic of pines. A portion of missed trees was attributed to interpretation oversight in height classes 1, 2 and 3 for a sample of plots located on cutover areas (Table 5). Missed trees however, were mostly attributable to seedling clumps that could not be counted easily. Seedling detection was otherwise high and exceeded $80 \%$ (Table 5). Incorrect stem counts within clumps would likely not influence stocking estimations since only one 


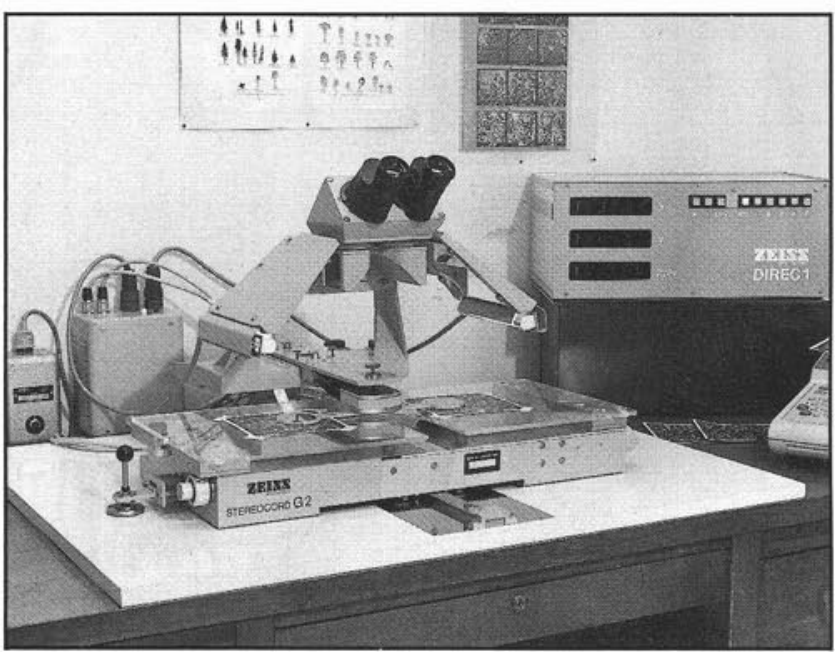

Figure 5. Photo measurement system consisting of a Zeiss Stereocord, digitizer and Hewlett-Packard desktop computer.

\begin{tabular}{lccccccc}
\hline Table 3. Distribution of the sixty paired photo-ground plots \\
\cline { 2 - 8 } & S1rata \\
Sites & CC1 & CC2 & CC3 & PC1 & PC2 & PC3 & Total \\
\hline PA2 & 3 & 8 & 4 & 3 & 2 & - & 20 \\
PA4 & 5 & 7 & 5 & - & - & - & 17 \\
DPRR2 & 1 & - & - & 4 & 11 & 7 & 23 \\
Total & 9 & 15 & 9 & 7 & 13 & 7 & 60 \\
\hline
\end{tabular}

seedling is required for a quadrat to be considered stocked (Stein 1978). For seedlings taller than two metres, clumping was less important because natural thinning processes reduced competition to dominant seedlings.

\section{(b) Seedling detectability over partial cut areas}

Partial cut sites had been planted with spruce at even spacing along cut strips. Although the planted trees were not clumped, detectability was occasionally influenced by the residual overstorey. A summary of seedling detectability by height classes for a sample of partial cut plots is provided (Table 6). Most of the missed seedlings were the results of interference from taller, partially flushed, residual trees. Since only 2 of the 60 paired plots contained planted trees without overstorey vegetation, an analysis of seedling detectability could not be made for plots unaffected by overstorey vegetation. Interpretation oversights were less frequent since most of the planted seedlings had achieved sizes ( $>30 \mathrm{~cm}$ tall) that rendered them more detectable on the large-scale photographs.

\section{Species Identification}

The purpose of the species identification test was to answer the question:

What was the accuracy of species interpretation of spruce and pine?

Of the total 4,460 seedlings occurring on the 60 plots, 2,858 were used for the species identification tests. This data set was further partitioned into the two height classes $<30 \mathrm{~cm}$ and $\geq 30 \mathrm{~cm}$ so the effect of tree size could be examined.

For all seedling heights, 96.4 percent of positively correlated trees were correctly identified (Table 7). Seedlings

\begin{tabular}{crrcc}
\hline \multicolumn{5}{l}{ Table 4 . Detectability of trees on $\mathbf{6 0}$ paired samples $\mathbf{( 4 \times \mathbf { 4 } \text { cluster } )}$} \\
\hline Stratum & Photo & Field & Difference & $\begin{array}{c}\text { Percent } \\
\text { detectability }\end{array}$ \\
\hline CC1 & 425 & 702 & -277 & 61 \\
CC2 & 1,719 & 2,531 & -812 & 68 \\
CC3 & 529 & 760 & -231 & 70 \\
PC1 & 83 & 155 & -72 & 54 \\
PC2 & 158 & 248 & -90 & 64 \\
PC3 & 42 & 64 & -22 & 66 \\
Total & 2,956 & 4,460 & $-1,504$ & 66 \\
\hline
\end{tabular}

less than $30 \mathrm{~cm}$ tall were correctly identified 85 percent of the time. Seedlings greater than or equal to $30 \mathrm{~cm}$, were correctly identified 97.3 percent of the time (Table 7).

\section{Accuracy of Percent Stocking and Density Estimates}

Percent stocking was the number of quadrats (or subplots) out of a cluster of 16,9 or 4 (expressed as a percentage) that contained one or more seedlings. Accuracy was the difference in stocking percentages obtained from the photos versus the field survey. The purpose of this analysis was to answer the questions:

1. What is the influence of photo plot cluster size on stocking estimates?

2. What is the accuracy of photo stocking estimates?

3. What is the accuracy of photo estimated stems per hectare (density)?

A comparison of average stocking by photo and field survey before correction or adjustment is presented (Table 8). The cluster configuration had little effect on total percent differences between photo and field. Larger variations in differences among the strata were observed however, for the smaller clusters (Table 8). The use of a smaller cluster size results in more variable stocking figures on an individual plot basis since the estimates are less continuous, but they would be reasonable on average (Table 8; Hall 1984). Smaller clusters are also faster to measure as double samples in the field.

The consistent differences between photo and field assessment of stocking and density (stems per hectare) were adjusted by a correction equation developed using regression analyses of the paired plots. The relationships between the photo and field measurements of stocking and density are shown in Figures 6 and 7, respectively. Photo stocking estimates were consistently lower by a $5 \%$ average than ground stocking measurements (Table 8 ). The regression relationship was therefore used to calibrate photo estimates of stocking. For density, although the regression between photo and ground density produced a high $R^{2}$, the large

\begin{tabular}{lrrrrr}
\hline \multicolumn{6}{l}{ Table 5. Percent detectability for 8 cutover plots } \\
\hline \multicolumn{2}{c}{$\begin{array}{c}\text { Height } \\
\text { classes }\end{array}$} & $\begin{array}{c}\text { Photo } \\
\text { plot }\end{array}$ & $\begin{array}{c}\text { Field } \\
\text { plot }\end{array}$ & Difference & $\begin{array}{c}\text { Percent } \\
\text { detectability }\end{array}$ \\
\hline 1 & $0-15 \mathrm{~cm}$ & 0 & 2 & -2 & 0 \\
2 & $16-30 \mathrm{~cm}$ & 65 & 148 & -83 & 44 \\
3 & $31-50 \mathrm{~cm}$ & 65 & 99 & -34 & 66 \\
4 & $51-100 \mathrm{~cm}$ & 118 & 183 & -65 & 64 \\
5 & $101-200 \mathrm{~cm}$ & 50 & 59 & -9 & 85 \\
6 & $201+$ & 15 & 16 & -1 & 94 \\
Total & 313 & 507 & -194 & 62 \\
\hline
\end{tabular}


Table 6. Percent detectability for 8 partial cut plots

\begin{tabular}{lrrrrr}
\hline $\begin{array}{l}\text { Height } \\
\text { classes }\end{array}$ & $\begin{array}{c}\text { Photo } \\
\text { plot }\end{array}$ & $\begin{array}{c}\text { Field } \\
\text { plot }\end{array}$ & Difference & $\begin{array}{c}\text { Percent } \\
\text { detectability }\end{array}$ \\
\hline 1 & $0-15 \mathrm{~cm}$ & 1 & 0 & 1 & - \\
2 & $16-30 \mathrm{~cm}$ & 0 & 1 & -1 & - \\
3 & $31-50 \mathrm{~cm}$ & 6 & 14 & -8 & 43 \\
4 & $51-100 \mathrm{~cm}$ & 14 & 21 & -7 & 67 \\
5 & $101-200 \mathrm{~cm}$ & 58 & 73 & -15 & 80 \\
6 & $201+$ & 8 & 9 & -1 & 89 \\
Total & 87 & 118 & -31 & 74 \\
\hline
\end{tabular}

Table 7. Correlations between field and photo identification of tree species for two height classes

\begin{tabular}{|c|c|c|c|c|c|c|c|c|c|}
\hline \multirow[b]{3}{*}{ Field } & \multicolumn{9}{|c|}{ Photo } \\
\hline & \multicolumn{3}{|c|}{ Height $<30 \mathrm{~cm}$} & \multicolumn{3}{|c|}{ Height $\geq 30 \mathrm{~cm}$} & \multicolumn{3}{|c|}{ All heights } \\
\hline & Pine & Spruce & Total & Pine & Spruce & Total & Pine & Spruce & Total \\
\hline Pine & 130 & 9 & 139 & 2181 & 27 & 2208 & 2311 & 36 & 2347 \\
\hline Spruce & 20 & 34 & 54 & 46 & 411 & 457 & 66 & 445 & 511 \\
\hline Total & 150 & 43 & 193 & 2227 & 438 & 2665 & 2377 & 481 & 2858 \\
\hline
\end{tabular}

Table 8. Comparison of average stocking by photo and field methods before corrections

\begin{tabular}{llllcccc}
\hline & & \multicolumn{5}{c}{ Percent stocking } \\
\cline { 3 - 8 } $\begin{array}{l}\text { Plot } \\
\text { configuration }\end{array}$ & $\begin{array}{c}\text { Cutover } \\
\text { type }\end{array}$ & $\boldsymbol{N}$ & $\begin{array}{c}\text { Photo } \\
\text { mean }\end{array}$ & $\boldsymbol{s}^{\mathbf{1}}$ & $\begin{array}{c}\text { Field } \\
\text { mean }\end{array}$ & $\boldsymbol{s}^{\mathbf{1}}$ & $\begin{array}{c}\text { Stocking } \\
\text { difference }\end{array}$ \\
\hline $4 \times 4$ & Cutover & 33 & 77 & 18 & 83 & 18 & 6 \\
& Partial cut & 27 & 31 & 26 & 35 & 27 & 4 \\
$3 \times 3$ & Cutover & 33 & 80 & 20 & 83 & 19 & 3 \\
& Partial cut & 27 & 28 & 25 & 34 & 30 & 6 \\
$2 \times 2$ & Cutover & 33 & 77 & 28 & 82 & 28 & 5 \\
& Partial cut & 27 & 29 & 30 & 34 & 31 & 5 \\
\hline
\end{tabular}

's represents standard deviation of percent stocking.

standard error of estimate suggested density estimates were not particularly good from large-scale photos. A small amount of double sampling with regression is recommended in every survey to verify the photo-ground relationship, and to develop the adjustment factors. The following regression equations were used in this project:

Adjusted percent stocking $=$ photo stocking $\times 1.01+4.19$ $R^{2}=0.96 S_{\hat{\mathrm{y}}}=6.9 \%$

Adjusted density $=$ photo density $\times 1.51-5.7$

$R^{2}=0.98 \quad S_{\hat{y}}=939$ stems $/$ ha

where $S_{\hat{y}}=$ Standard error of estimate

\section{Discussion}

\section{Preliminary Stratification}

The six cutover sites were photo interpreted on the $1: 10,000$ colour photos and mapped at 1:12,500. The primary purpose of the preliminary classification was to provide an overview of the target areas for planning purposes, and to develop the LSP sampling design.

The preliminary interpretation was originally more detailed than the final stratification because the sites revealed considerable variability in stocking levels. At the request of Weyerhaeuser Canada, however, the photo interpretation was revised to generalize and enlarge the types and thereby simplify the maps. A 20-ha cell size was considered the minimum for economical site treatment. As explained in the next section, this change had a considerable negative impact upon the effectiveness of the $1: 10,000$ photo interpretation of stocking and sampling efficiency. There was as much stocking variation within stratified units as there were between units.

\section{Stocking and Density Estimation}

The sampling design for the cutover survey was based on the preliminary $1: 10,000$ photo interpretation and mapping of the six sites. The samples were selected sequentially, according to design specifications and using some $a$ priori information on expected stocking variability for these six strata. A random selection was drawn and listed in the order selected. The sample plots were interpreted and measured until the required accuracy of \pm 10 percent ( $95 \%$ confidence level) was reached for the six sites and associated strata. More plots were drawn if a particular site and stratum did not attain the prescribed accuracy. In a few cases, the stratum was too small to be sampled adequately. The LSP compilation software was used to check the accuracy levels periodically and yielded percent stocking and density statistics (Table 9). The equations developed in the preceding section were used to adjust the percent stocking and density estimates.

Stocking and density results (Table 9) can be used to check the photo interpretation classification (pre-stratification) of the cutovers. Fully stocked (CC1 or PC1) areas should have a higher stocking and density than partially stocked classes (CC2 or PC2), and the latter should have higher values than unstocked classes (CC3 or PC3). Such trends were not evident, however, as some areas classified as NSR (CC3 or PC3) were of higher stocking or density than the fully stocked category. The pre-stratification clearly did not work well and two explanations were proposed:

1. The poor correlation may be explained partly by the inability of the photo interpreter to distinguish useful indicators of stocking levels on the 1:10,000 photos. Considering the scale resolution limitation, a crown of $25 \mathrm{~cm}$ diameter or smaller, would likely not be seen and those with a 30 to $40 \mathrm{~cm}$ crown, would be difficult to detect. Thus, a larger mapping scale of perhaps $1: 5,000$ to $1: 8,000$, should have been used for targets of this size.

2. The relationship between the actual size of the cutover categories and the 20 ha minimum area restriction likely influenced the stratification results. If the actual size is smaller than the minimum area, the photo interpretation would tend to "average" dissimilar units into simpler, larger units. This prevents the interpreter from identifying and classifying real stocking or density differences. In this study, the stocking and density differences were originally mapped in fine detail. The resulting small type delineations however, did not suit the operational needs of the user and the interpreter was required to aggregate the types into larger units. The aggregation largely defeated the stratification goal. In practice, both the photo scale limitation and the minimum type size restriction likely combined to produce the poor stratification results.

\section{Summary of Production Times and Costs}

A record was kept of the times and costs required to complete the tasks outlined earlier under survey method: 


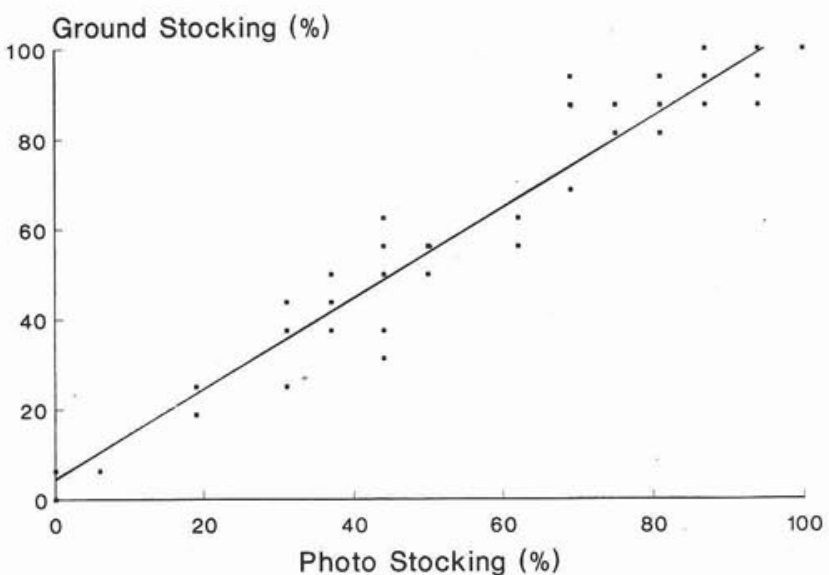

Figure 6. Regression relationship of percent stocking between photo and ground survey.

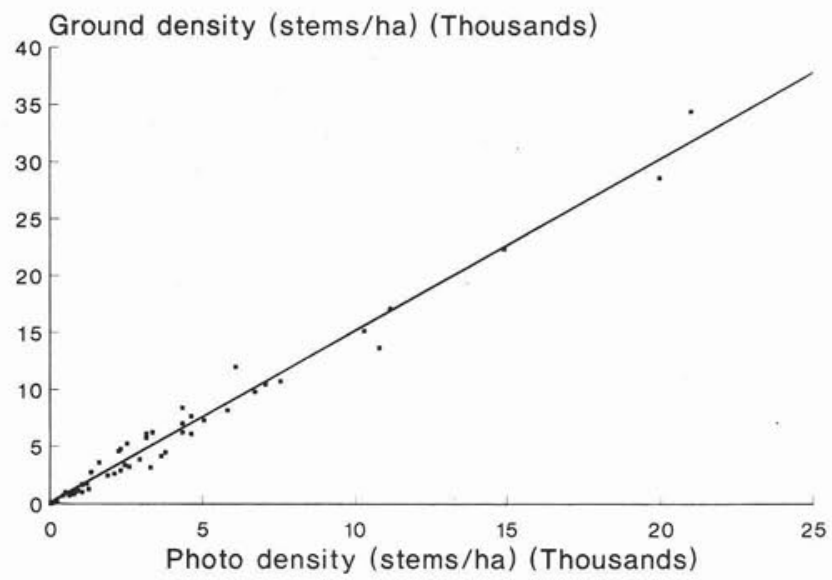

Figure 7. Regression relationship of density in stems/ha between photo and ground survey.

- acquisition of general coverage colour photos

- photo interpretation and mapping

- sampling design

- acquisition of large-scale sampling photos

- photo measurement

- field work

- compilation of results.

Since many tasks involved development and testing of procedures and were being done for the first time, costs were higher than what would be achieved in an operational application. In this study, paired-sample tests were particularly labour intensive. Instead of 60 plots, perhaps 15 or 20 field plots would normally be used to check and calibrate photo measurements. Cost elements in this study were analyzed and estimated to be about double the costs that would be achieved in a production line. Costs also are strongly influenced by the size of the job, local conditions, aircraft availability, accessibility, labour costs and other factors. The cost per plot cluster done on a production job would most likely range between $\$ 10$ and $\$ 15$ per hectare, or $\$ 30$ and $\$ 35$ per plot. This includes the mapping of six sites totalling about 2000 ha, the sampling of up to six stocking categories per site to an accuracy of \pm 10 percent ( 95 percent confidence).

\section{Summary and Recommendations}

Conifer tree seedlings $30 \mathrm{~cm}$ and taller were readily detected at photo scales of 1:500 to 1:800, provided the trees were not hidden beneath larger trees, nor lost in dense patches of trees or brush of similar size. On partial cutovers, the residual conifers interfered with seedling detectability. Residual hardwoods normally interfere much less with detectability but did in this study because of the advanced state of leaf flush. Although some trade-off is necessary, tree phenology should take precedence over sun angle in determining the optimal period for photo acquisition.

In this study, brush cover did not interfere with detectability. Where natural regeneration had been particularly successful however, dense clumps of seedlings frequently influenced the detectability of individuals. Although about one-third of the trees could not be counted on the photos, clumping would also pose difficulties in field density estimates. The fairly large differences between photo and field estimates suggest large-scale photos should not be used for density counts.

Stocking estimates were not seriously influenced by clumping due to greater emphasis on the spatial distribution of trees. Estimates of stocking from individual $4 \times 4$ plots (consisting of sixteen $5-\mathrm{m}^{2}$ quadrats) should not be biased by more than 5 percent and variation should be within \pm 7 percent ( $67 \%$ confidence). Photo estimates were readily adjusted using regression techniques.

The $3 \times 3$ (i.e., 9 quadrats) and $2 \times 2$ (i.e., 4 quadrats) sample plot configurations exhibited no sign of additional bias on average in the stocking or density estimates. Increased variability can be expected however, for smaller clusters. The $4 \times 4$ photo plot size of 16 quadrats took very little extra time to measure and is recommended for future work.

The identification of jack pine and spruce was correct 96 percent of the time for all seedling sizes, and was slightly higher for trees taller than $30 \mathrm{~cm}$. Since white or black spruce and balsam fir were considered acceptable species, there was no specified requirement to separate them. On large-scale normal colour photos, white and black spruce are inseparable, and confusion with balsam fir seedlings is common on smaller seedlings (Hall 1984).

The photo interpretation of the $1: 10,000$ colour photographs enabled the cutovers and non-forest areas such as bodies of water, roads, landings, clearings, brush areas, etc., to be clearly delineated and mapped. The preliminary separation of unstocked, partially stocked or fully stocked areas did not agree well with the data collected on the samples. Several explanations can be made. First, the scale resolution limitation of the 1:10,000 photos may preclude detection of small seedlings. Second, the photo interpreter may have had difficulty relating visual cues to the background context (topography, soil textures, nature of harvesting, site preparation and regeneration method, etc.). Third, if stocking variations occur as small areas that are less than the minimum type size ( $20 \mathrm{ha}$ in this project), then stocking variations would be inadequately mapped. Stratified units would consequently contain mixtures of stocking levels that would render them more similar to one another, thus reducing the stratification advantage. All three reasons could have existed, but the latter was likely the main source of error. Limited tests with larger photo scales (e.g., 1:5000 to 1:8000) is warranted to better identify the stocking interpretation limitations. 
Table 9. Adjusted percent stocking and density results

\begin{tabular}{|c|c|c|c|c|c|c|c|c|c|}
\hline \multirow{2}{*}{\multicolumn{2}{|c|}{ Density }} & \multirow[b]{3}{*}{$\mathbf{N}$} & \multicolumn{7}{|c|}{ Percent stocking } \\
\hline & & & \multicolumn{2}{|c|}{ Spruce } & \multicolumn{2}{|c|}{ Pine } & \multicolumn{2}{|c|}{ All species } & \multirow[b]{2}{*}{ Stems/ha } \\
\hline Site & Stratum & & Mean & Error $^{1}$ & Mean & Error $^{1}$ & Mean & Error $^{1}$ & \\
\hline PA1 & $\begin{array}{l}\mathrm{CC} 1 \\
\mathrm{CC} 2 \\
\mathrm{CC}^{2}\end{array}$ & $\begin{array}{l}38 \\
53 \\
10\end{array}$ & $\begin{array}{l}22.0 \\
20.0 \\
12.3\end{array}$ & $\begin{array}{r}7.4 \\
5.9 \\
12.2\end{array}$ & $\begin{array}{l}87.3 \\
71.4 \\
89.2\end{array}$ & $\begin{array}{r}7.8 \\
9.6 \\
12.3\end{array}$ & $\begin{array}{l}92.0 \\
78.1 \\
90.5\end{array}$ & $\begin{array}{r}6.1 \\
8.2 \\
10.6\end{array}$ & $\begin{array}{l}29,829 \\
17,615 \\
29,011\end{array}$ \\
\hline PA2 & $\begin{array}{l}\mathrm{CC}^{2}{ }^{2} \\
\mathrm{CC} 2 \\
\mathrm{CC} 3 \\
\mathrm{PC}^{2}{ }^{2} \\
\mathrm{PC}^{2}\end{array}$ & $\begin{array}{r}6 \\
60 \\
49 \\
5 \\
16\end{array}$ & $\begin{array}{l}27.1 \\
29.7 \\
26.9 \\
35.5 \\
28.4\end{array}$ & $\begin{array}{r}16.9 \\
5.9 \\
6.5 \\
34.7 \\
10.8\end{array}$ & $\begin{array}{r}62.5 \\
54.4 \\
72.4 \\
13.0 \\
6.5\end{array}$ & $\begin{array}{r}33.9 \\
9.9 \\
8.2 \\
11.4 \\
3.3\end{array}$ & $\begin{array}{c}75.0 \\
9.6 \\
79.5 \\
43.0 \\
30.8\end{array}$ & $\begin{array}{r}23.1 \\
7.3 \\
6.9 \\
32.3 \\
10.2\end{array}$ & $\begin{array}{r}9,776 \\
12,201 \\
12,534 \\
33,010 \\
2,810\end{array}$ \\
\hline PA3 & $\begin{array}{l}\mathrm{CC}^{2}{ }^{2} \\
\mathrm{CC} 2 \\
\mathrm{CC} 3\end{array}$ & $\begin{array}{l}41 \\
55 \\
47\end{array}$ & $\begin{array}{l}12.3 \\
18.5 \\
21.6\end{array}$ & $\begin{array}{l}2.9 \\
4.9 \\
5.5\end{array}$ & $\begin{array}{l}42.6 \\
41.5 \\
57.5\end{array}$ & $\begin{array}{r}11.7 \\
10.0 \\
9.4\end{array}$ & $\begin{array}{l}49.0 \\
49.3 \\
65.2\end{array}$ & $\begin{array}{r}10.4 \\
9.8 \\
8.8\end{array}$ & $\begin{array}{l}5,920 \\
6,135 \\
9,314\end{array}$ \\
\hline PA4 & $\begin{array}{l}\mathrm{CC} 1 \\
\mathrm{CC} 2 \\
\mathrm{CC} 3\end{array}$ & $\begin{array}{l}54 \\
44 \\
54\end{array}$ & $\begin{array}{l}18.3 \\
14.3 \\
18.4\end{array}$ & $\begin{array}{l}4.3 \\
4.3 \\
4.1\end{array}$ & $\begin{array}{l}88.7 \\
78.9 \\
54.5\end{array}$ & $\begin{array}{l}5.9 \\
8.0 \\
8.8\end{array}$ & $\begin{array}{l}93.6 \\
81.6 \\
62.1\end{array}$ & $\begin{array}{l}4.1 \\
7.2 \\
7.8\end{array}$ & $\begin{array}{l}29,272 \\
19,916 \\
10,438\end{array}$ \\
\hline DP1 & $\mathrm{PC} 2$ & 33 & 16.3 & 4.1 & - & - & 16.3 & 4.1 & 493 \\
\hline DP2 & $\begin{array}{l}\mathrm{CC}^{2} \\
\mathrm{CC} 2^{2} \\
\mathrm{CC} 3^{2} \\
\mathrm{PC} 1 \\
\mathrm{PC} 2 \\
\mathrm{PC} 3\end{array}$ & $\begin{array}{r}22 \\
28 \\
11 \\
9 \\
78 \\
42\end{array}$ & \begin{tabular}{r|r|}
17.8 & \\
13.1 & \\
16.1 & \\
7.7 & \\
28.3 & \\
21.6 &
\end{tabular} & $\begin{array}{l}9.0 \\
7.1 \\
6.3 \\
4.1 \\
5.5 \\
6.5\end{array}$ & $\begin{array}{r}56.8 \\
7.3 \\
16.7 \\
- \\
- \\
-\end{array}$ & $\begin{array}{l}19.2 \\
3.3 \\
9.8 \\
- \\
- \\
-\end{array}$ & $\begin{array}{c}68.7 \\
15.6 \\
27.5 \\
7.7 \\
28.7 \\
21.6\end{array}$ & $\begin{array}{r}14.9 \\
7.8 \\
13.9 \\
4.1 \\
5.5 \\
6.5\end{array}$ & $\begin{array}{r}6,374 \\
1,411 \\
1,332 \\
107 \\
1,381 \\
910\end{array}$ \\
\hline Total & & 755 & & & & & & & \\
\hline
\end{tabular}

$195 \%$ confidence level.

${ }^{2}$ Area too small to sample adequately.

A smaller minimum size than 20 ha would be necessary to achieve the benefits of stratification. A smaller minimum area size combined with a larger scale (e.g., 1:5000) would allow for increased detail in stratification, more homogeneous units, and a more efficient allocation of photo plots. Such a map in itself may be suitable alone for certain applications. The map scale, level of detail for stratification, and whether to implement LSP would depend greatly on the specific information needs.

The two-stage sampling design used was more complicated than need be due to the generalization of the mapped stocking levels. The PSU's (sample strips) could have been selected such that each strata unit would receive about the same length of large-scale photo coverage. The SSU's (plots) would then be selected according to the same random process until each stratum received about the same number of plots, perhaps 30 to start with in this study. Sequential sampling would then be used to compile the results and to check whether the required accuracy of stocking estimates had been reached. If not, more samples should be selected, measured and a recompilation carried out. The number of photos taken per stratum should allow for the possible selection of at least 75 samples. A simpler procedure can be used because the stocking variation did not change much from one stratum to the other, nor with the size of the stratum. If a sharper separation of stocking levels could have been made at the preliminary interpretation stage as was the intention, then the sample allocation scheme would have been adjusted toward the more elaborate design. In general, the two-stage, double-sampling with regression design was suitable. The regression relationships between photo and field samples were used to calibrate the photo estimates of stocking and density.
Spring is preferred over the fall leaf-off "window" for both stratification and large-scale photo missions due to the larger sun angles. If a project was to span several years, the first photo mapping mission should be carried out in the spring window with the fall window used as a "fall back" opportunity, or to fill-in if problems occurred in the spring coverage. The LSP would then proceed the following spring after the stratification had been completed. At the same time, the next year's mapping photo coverage would proceed. The following fall window could then be used as a fall-back strategy for either $1: 10,000$ or LSP coverage. The cycle could then be repeated for whatever number of years are required to complete the project. Although the colour film Kodak 2448 was found to provide excellent results, the faster 2445 film could be considered as an alternate for the fall photo missions. Agfa, however, has also produced two relatively high speed, wide exposure latitude colour films in both the diapositive (Avichrome 200) and negative (Avicolor 200) forms, that should be considered for critical spring or fall photography.

\section{Acknowledgments}

The initiative, assistance and cooperation by Weyerhaeuser Canada Ltd. and the opportunity to conduct the study in an operational context are gratefully acknowledged. Mr. Roman Orynik of Weyerhaeuser is especially thanked for his advice and support through all stages of the project. The cooperation and input by the Saskatchewan Department of Parks and Renewable Resources, particularly Ms. Corrine Nelson (formerly with SPRR), is appreciated. The project was funded under the Canada/Saskatchewan Forest Resources Development Agreement, and the administrative and technical assistance of Mr. Alex Gardner (formerly with the 
Saskatchewan District Office of Forestry Canada) is greatly appreciated. Early discussions on regeneration assessment with M. Godfrey of Timberline are also gratefully acknowledged.

\section{References}

Ashely, M.D. and W.B. Cohen. 1985. Making a regeneration survey using aerial photography. Col. of For. Res., U. of Maine, Orono, Maine, Misc. Rep. 308, 15 p.

Befort, W. 1988. Controlled scale aerial sampling photography: development and implications for multi-resource inventory. J. For. 86(11): 21-28.

Ball, W.J. and V.S. Kolabinski. 1979. An aerial reconnaissance of softwood regeneration on mixedwood sites in Saskatchewan. Env. Can., Can. For. Serv., North. For. Res. Cent., Edmonton, Alta., Inf. Rep. NOR-X-216, 14 p.

Bonnor, G.M. 1975. Cluster sampling with large-scale aerial photography in forest inventories. Env. Can., Can. For. Serv., For. Mgmt. Inst., Ottawa, Ont., Info Rep. FMR-X-80, 26 p.

Butler, J.M. 1983. Regeneration Surveys from the air using largescale aerial photography. Env. Can., Can. For. Serv., Nfld. For. Res. Cent., St. John's, Nfld. Woody Points Vol. 12(1), $2 \mathrm{p}$.

Dendron Resource Surveys. 1983. Discussion paper on forest stocking. Contract Report for Can. For. Serv., Forestry Statistics and Systems Branch, Petawawa, Ont., 21 p.

Goba, N., S. Pala and J. Narraway. 1982. An instruction manual on the assessment of regeneration success by aerial survey. Ont. Min. Nâi. res., Ont. Cent. Remote Sensing, Toronto, Ont., 49 p.

Hall, R.J. 1984. Use of large-scale aerial photographs in regeneration assessments. Env. Can., Can. For. Serv., North. For. Res. Cent., Edmonton, Alta., Inf. Rep. NOR-X-264. 39 p.

Hall, R.J., D.J. Morgan and R.H. Bowlby. 1984. Application of large-scale photographs to forest resource inventories: what are the options? Pages 643-652 in: Proceedings of the 9th Canadian Symposium on Remote Sensing.

Hazard, J.W. and I.E. Stewart. 1974. Planning and processing multi-stage samples with a computer program - MUST. U.S.D.A. For. Serv. Gen. Tech. Rep. PNW-11, 15 p.

Hudson, W.D. 1985. Monitoring silvicultural activities with aerial photography. Cent. For. Rem. Sensing, Dep. of For., Michigan State U. 63 p.
Kirby, C.I. 1980. A camera and interpretation system for assessment of forest regeneration. Env. Can., Can. For. Serv., North For. Res. Cent., Edmonton, Alta., Info. Rep. NOR$\mathrm{X}-221,8 \mathrm{p}$.

Kuhnke, D.H. 1989. Silviculture statistics for Canada: an 11-year summary. Env. Can., Can. For. Serv., North. For. Res. Cent., Edmonton, Alta., Inf. Rep. NOR-X-301, 81 p.

MacLeod, D.A. 1981. A guide to strip sampling for forest inventory using large-scale aerial photography. Env. Can. Can. For. Serv., Petawawa Nat. For. Inst., Petawawa, Ont., Inf. Rep. PI-X-7, 23 p.

MacLeod, D.A. 1982. Project report: analysis of regeneration surveys. Env. Can., Can. For. Serv., North. For. Res. Cent. Unpublished project No. T801, 19 p.

Nielsen, U., A.H. Aldred and D.A. MacLeod. 1979. A forest inventory in the Yukon using large-scale photo sampling techniques. Can. For. Serv., For. Manage. Inst., Ottawa, Ont., Inf. Rep. FMR-X-121, 40 p.

Price Waterhouse Associates. 1984. N.F.R.C. Market Research Study - Large-scale photo sampling system. Price Waterhouse Associates, Edmonton, Alta. Unpublished report for Environment Canada, March, 1984, 22 p.

Rowe, J.S. 1972. Forest Regions of Canada. Env. Can., Can. For. Serv., Ottawa Ont. Publ. 1300, 172 p.

Saskatchewan Parks and Renewable Resources. 1985. Regeneration survey manual. Forestry Division, Silviculture Section. $15 \mathrm{p}$.

Smith, J.I., C.D. Campbell and R.A. Mead. 1986. Imaging and identifying loblolly pine seedlings after the first growing season on $35 \mathrm{~mm}$ aerial photography. Can. J. Rem. Sensing, 12(1): 19-27.

Spencer, R.D. and R.J. Hall. 1988. Canadian Large-scale aerial photographic systems (LSP). Photo. Eng. Rem. Sensing, 54(4): 475-482.

Stein, W.I. 1978. Reforestation evaluation. Pages 206-221 in: Regenerating Oregon's Forests. Oregon State University, School of Forestry, Corvallis, Oregon.

\section{CIF/IFC Corporate Sustaining Members}
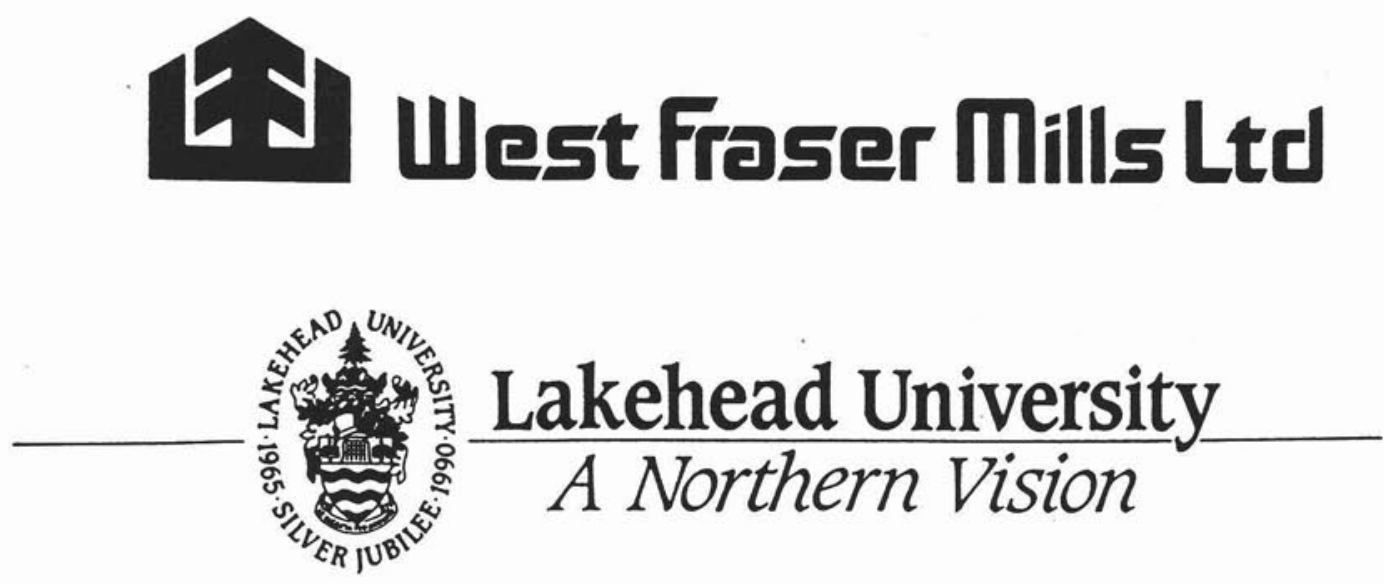